\title{
COLLOQUIAL LANGUAGE USED IN MOVIE SCRIPT ADA APA DENGAN CINTA 1
}

\author{
Imam Arif Hidayat, Muhammad Kiki Wardana \\ Universitas Harapan Medan, Medan, Indonesia \\ e-mail: imam230095@gmail.com
}

Received: 2021-10-23

Accepted: 2021-11-26

\begin{abstract}
This study is conducted to examine colloquial expression in the movie script Ada Apa dengan Cinta I. Colloquial Language is the linguistic style used for casual communication. The method applied in this study is qualitative approach. The data shows that there are 28 occurances of colloquial expression in the movie script. The expressions involve five types. They are slang, jargon, provanity, contraction and idiom. The most dominat expression used in the movie is slang with $42.9 \%$ occurances. The second position is provanity with $25 \%$ occurances. Then, the next level is jargon with $17.9 \%$, contraction with $10.7 \%$, and the last is idiom with only $3.5 \%$ occurances. The result shows that the movie script presents a casual conversation. Most situation of the conversation is informal. Moreover, this movie script is identical with teenagers as the most characters are teenagers. The teenagers tend to use such casual conversations. Besides, the result proves that this movie script also presents a local dialect of Bahasa Indonesia. It is Jakarta dialect since the setting is in that region. Therefore, it is concluded that this movie is characterized with Jakarta dialect and teenager's casual conversation.
\end{abstract}

Keywords: Colloquial, local dialect, language variety, casual conversation

\section{Introduction}

Language is the important necessity of human life in this world. People use language to deliver what they want to speak to the other. Wardhaugh (in Srijono, 2001:1) says, "Language is a system of arbitrary vocal symbols used for human communication". In human communication, there are two forms of language, spoken language and written language. People use spoken and written language in the daily life to facilitate in communication Language has a lot of functions to the people in daily life. SriJono (2001:7) explains, "people use language for different purposes. They use language for communication, persuasion, information, introduction, negotiation, and for socialization". For the communication, language can share anything to each other. Language and literature cannot be separated from each other. Language is the basic raw material or medium, through which literature is produced, whether they are novels or poems, plays or films, and etc. Then, language has been defined by Hornby (2000: 752) as a system of communication in speech and writing that is used by people of a particular country or area. It is a system for the expression of thoughts, feelings, etc., by the use of spoken words or conventional symbols. Literature, whether oral or written, expresses people's thoughts, feelings, views, culture, etc (Hornby, 2000: 783). 
Literature cannot exist outside language since language is the medium of expression. Fowler in Nurgiyantoro (1994: 271) says that literature is the world that was created, built, offered, and realized through words or language. People can only use language to construct poems, stories, plays, films, etc. In other words, literature involves the manipulation of language for creative purposes. Language evolves and deviates in society as the product of human culture.

The phenomena of language deviation are then studied under stylistics. Leech (1969: 1) says that stylistics is simply the study of literary style, even more explicit, the study of the use of language in literature. The tendency is also supported by Turner (1977:7). He defines stylistic as a part of linguistic studies which concerns with the variation of language use. It can be defined as the analysis of distinctive expression in language and the description of its purpose and effect.

Further, stylistic analysis can direct attention to specific linguistic features in a text and so provide textual substation for the different kinds of literary effect it might have on the reader. Quirk (2001:789) stated that language is the system of communication in speech and writing that is used by people of a particular country. According to Al-khulli (1976:7) language is an arbitrary vocal symbol used to communicate ideas and express feeling among the members of certain social community.

The movie Ada Apa Dengan Cinta 1 portrays tenager story. It presents many slang words for teenagers. The movie invites the spectators to know about the variation of non-standard English. Based on the phenomenon, this study examines colloquial language in $A A D C 1$ movie. This study is purposed to find out the colloquial occurances in the forms and the process of morphological aspect. Here, morphological process concerns with how slang word is formed. The reason of conducting the research is that there are some slang words seen to have the similarity in word formation. It is important to study about slang word because slang is widely used by many groups of society and it potentially creates new word. The types of colloquial language discusseed in this study are: jargon is the specialized terminology associated with a particular field or area of activity; slang is a very informal language or specific words used by a particular group of people; idiom is a phrase or expression whose meaning cannot be understood from the ordinary meanings of the words in it; contraction is the action or process of contracting the state of being contracted; profanity is a type of language that includes dirty words and ideas. This research can help readers to understand the instructional design for teaching speaking especially in the colloquial language in the $A A D C 1$ movie.

\section{Literature Review}

\subsection{Sociolinguistes}

Sociolinguistics is one study about language about society Condition. The study of language about society, i. e. sociolinguistics (Hudson 1996), is under the umbrella of the functionalist approach or structural functionalism as Williams (1992) suggests. Historically, sociolinguistic research has been concerned with "communication and interaction, linguistic variation and language varieties, the social function of language use, language change and development", a list that "would include work done in the ethnography of communication, discourse analysis, dialectology, sociolinguistic variation, the sociology of language, pragmatics, stylistics, pidgin [and] creole studies" (Figueroa 1994: 24). This list is not exhaustive and, for example, I would include 
studies on language planning (e. g. Fishman 1989) and linguistic rights (e. g. Patrick/Packer, to appear).

Even though sociolinguistic research is ascribed to the functionalist ontology of language, by applying different research methodologies, each type of sociolinguistics may coin its ontology of language. There is not a unified sociolinguistic theory (see Nevalaine/Raumolin-Brunberg 2003) and perhaps there is no need for one, but if one is established it should preserve its multidisciplinary character and diversity in research methods (Coupland 2016).

Coupland (2001) suggests three ways in which sociolinguistic theory could be regarded as 1) sociolinguistics as a "proper" linguistic theory; 2) sociolinguistics as an accumulation of socially-relevant mini-theories, and 3) sociolinguistics as a social theory. Coupland discards the first one since after almost forty years mainstream linguistics has remained "a theory about language without human beings" (Coulmas 1997: 4), so "the theoretical impact of sociolinguistics must be made elsewhere" (Coupland 2001: 5). For the second type, Coupland asserts that many sociolinguists would agree with it (e. g. Hudson 1996; Wardhough 2006) since sociolinguistics has produced "theories but not theory" (Coulmas 1997: 3).

Language variety is one of the object study's sociolinguistics. According to Coupland (2007: 4), the definitions of sociolinguistics refer to studying language "in society or "language" in its social contexte and some definitions focus on studying linguistic diversity or language variation.

Hudson in Wardhaugh (1998: 21) says that the variety of language is a set of linguistic items with similar distributions. Hudson and Ferguson in Wardhaugh (1998: 21) agree that variety is defined in terms of a specific set of linguistic items or it is defined as a human speech pattern.

Chaer, A. (2003: 62) there are two types of language variation are distinguished by their use status. First is High Language Variation $(\mathrm{H})$ and the second is Low Language Variation (L). Usually $\mathrm{H}$ uses in formal conditions, such as: state speech, the language of instruction in education, textbooks, and a formal letter. And it must be learned through formal education at school. Meanwhile, language always uses in informal conditions, such as: at home, private letter, street, etc. This variation can be taught in public, never been in formal education.

\subsection{Definition of Colloquial}

Colloquialism originated from the Latin "colloquium" means "conference" or "conversation". So, colloquialism means informal language or everyday language (Jalalpour \& Hossein, 2017), in general, colloquialism is an informal word or expression used in conversation between an ordinary person or an educated person. Epoge (in Hasanah, 2020) said that Colloquial speech refers to the total set of utterances in a familiar, informal context such as at home, at a place of relaxation or at the workplace. Based on the theory above, it can be concluded that colloquialism is an unofficial word, expression, and phrase that is commonly used for conversation or writing between ordinary people and educated people.

Torchia, C. (2007: 8) Colloquial Indonesian is constantly evolving, and often bears little resemblance to the "correct" written form of the language, a source of concern to some linguistics. Such a divergence is common in languages worldwide, but the vast ethnic mix and breadth of linguistic influences in Indonesia deepen the trend. It means Jakarta is the center of everything trendy and thus a huge influence on the whole 
of the country, at least open to contacts with outside through people travel, migration, and so on.

Colloquialisms are generally geographic, in that a colloquial expression often belongs to a regional or local dialect. They can be words, phrases, or aphorisms (see below for examples). The Jakarta colloquial is recognizable because of its particular characteristics, which can be summarized under three areas:

\section{Word-forms}

The system of affixation differs from standard Indonesian in the following ways:

- The prefix me- is absent, and different rules of nasalization apply.

- The suffixes -kan and $-\mathrm{i}$ are replaced by $-\mathrm{in}$.

Some examples:

Temenin : "to keep someone company," standard: menemani

Rasain : "to feel," standard: merasakan

\section{Sounds}

The vowel a is replaced by e in a final syllable, e.g. dapat (get) becomes dapet; and senang (happy) becomes seneng.

\section{Words}

There are also typical, frequent words, such as:

$\begin{array}{lll}\text { Low Variation } & \text { High Variation } & \text { Meaning } \\ \text { Kayak } & \text { Seperti } & \text { like } \\ \text { Banget } & \text { Sekali } & \text { very }\end{array}$

\subsection{Types of Colloquial}

There are many particles that often be spoken while speaking Indonesian. A foreigner that has learnt Indonesian and comes to Indonesia will of course be confused with so many 'words' that he/she does not understand. Even when an Indonesian himself, if he/she never has thought about the particles, the meaning is also not understood. For example, while eating meatball soup, a friend comes from behind and asks, "Lagi makan apa sih? ("What are you eating sih?"). This "sih" has no specific meaning, it only expresses feeling. This is the advantage of using Indonesian than English, because there are so many words indicating feeling. (http://inggrisindo.blogspot.com/2008/02/slang-particles-in-indonesian-language.html)

1. Indeed / of course / You should have known that ...

Kamu dapet kue gratis juga? Dapet dong = Did you get the free cake? Of course I got it.

2. By the way (changing topic)

Eh, inget ga tempat ini? = By the way, do you remember this place?

3. Because

Kenapa ga masukin kulkas aja? - Mana cukup, kan kulkasnya kecil = Why don't you put it in the fridge? - It's not enough, because the fridge is small.

4. Why (asking) / I wonder why (just expresses wonder)

Kok kamu telat? = Why are you late?

Kok bisa dia dipukul papanya, aneh = I wonder why he is attacked by his father, it's strange.

5. Expressing surprise after hearing something 
Loh, katanya ga mau ikut? - Pikir-pikir pengen juga = What? Didn't you say that you didn't want to join us? - After thinking, I became more interested.

Aku bolos aja deh - Loh, kenapa? = I think I will skip (the lecture) (for now) What?! Why is it?

\subsection{Slang}

According to Yule (2010: 259), is more typically used among those who are outside the established higher-status group. Sometimes it is used by the younger speakers. Still, slang could be characterized as an extremely informal language embracing new and impolite either words or meanings. It is regularly spoken among particular groups of people who have a conversation in a not serious matter, such as a group of teenagers or entertainers. According to Spolsky (1998:36) slang is a feature of the speech of the young and powerless. Slang is a kind of jargon marked by its rejection of formal rules. According to Leech and Short (1981: 26), slang is a language used by a particular social group to show intimacy and solidarity among its members which are not fully understood by those outside the group.

The following are the example of slang:

1. "The kids were ready to bite my arm off just because I promised to take them to the candy store."

2. "I can't believe my life has passed so quickly. Now that I am in the hospital, I'll probably just kick the bucket here."

3. "I can't believe she went and told my father about everything just to get me in trouble, what a hater."

4. "I got a job promotion even though I don't go to work half the time. I'm so sick."

5. "I'm so upset about my birthday party pictures. My brother is making faces behind me in every picture, what a photobomb!"

\subsection{Jargon}

Language is a tools in communication, the development of language have an alteration or new words. According to Brown and Attardo (2000:118), jargon is some special terms that refer to the activity of occupational varieties. As Fromkin et. Al. (2011:470) said that Linguistic jargon, some of which is used in this book, consists of terms such as phoneme, morpheme, case, lexicon, phrase structure rule, and so on.

The jargon used by different professional and social groups is so extensive (and so obscure in meaning).

For example:

1. I need a script to pick up the medicine. (medical jargon for "prescription")

2. I need a nurse to room 12 stat. (medical jargon for "in a hurry")

3. Your objection is overruled. (legal jargon)

4. We need to take data points to determine if there has been a response to the intervention. (educational jargon).

5. The suspect is headed west on Route 10. All available units, respond. (police jargon).

\subsection{Idiom}

Moon (1998:3) says that idiom is "an ambiguous term, used in conflicting ways."According to Wright, J. (2002:7), the idiom is an expression that has two features: the idiom is fixed and is recognized by native speakers; idiom uses language in a non-literal - metaphorical - way. Idiom uses language in a non-literal- metaphorical - 
way in a definition is given by Larson (1984:20) idiom is a string of words whose meaning is different from the meaning conveyed by the individual words.

Example of Idiom:

\begin{tabular}{|c|c|c|}
\hline Idiom & Meaning & Usage \\
\hline Break a leg & Good luck & By it self \\
\hline Call it away & $\begin{array}{c}\text { Stop working on } \\
\text { something }\end{array}$ & As part of a sentence \\
\hline Easy does it & Slow down & By it self \\
\hline A dime a dozen & Something common & As part of a sentence \\
\hline
\end{tabular}

\subsection{Constraction}

Constraction is a shortened version of the written and spoken forms of a word, syllable, or word group, created by omission of internal letters and sounds.whose phonology, grammar, and vocabulary, instead of having developed naturally, are consciously devised. In most contractions, an apostrophe represents the missing letters. The most common contractions are made up of verbs, auxiliaries, or modals attached to other words: It is $=$ it ' is. I' $a m=I ' m$. They are $=$ They're.

Example of Constraction:

\begin{tabular}{|c|c|}
\hline English & Indonesia \\
\hline I'am $=$ I'm & Saya $=$ Awak \\
\hline He is $=$ He's & Dia $=$ Ia \\
\hline You are $=$ You' re & Kamu $=$ Ko \\
\hline They are $=$ They' re & Mereka $=$ Orang \\
\hline It is $=$ It'is & Itu $=$ Nah \\
\hline
\end{tabular}

\subsection{Profanity}

Profanity an English term denoting a particular type of linguistic Behavior, it is often used in studies of other languages to denote a linguistic resource whose functions and realizations across languages are remarkably similar and seem to emanate from a common pool of emotive utterance types (Ljung, 2011:1).

According to Allan and Burridge (2006:12), taboos arise out of social constraints on the individual's Behavior where it can cause discomfort, harm, or injury. According to Swan (1995:575), profanity is a strong language that is expressed by a person to their powerful emotion. It shows that swear word is used by the person to show his emotions with someone else.

\section{Research Method}

The methodology is absolutely needed in any research in order to find the accurate, and effective research. In this study, qualitative method is used. Research method will help the researcher to collect, analyse, and interpret data and answer research questions (Creswell, 2012; Johnson \& Christensen, 2008). Ary et. Al. (2010:424) states that the qualitative inquirer deals with data that are in the form of words or pictures rather than numbers and statistics. Thus, the method of qualitative research in this study deal with data about of colloquial language used in the movie. 
The material of this study focused on selected short stories was retold by Slamet Riyanto. Data in the form of quotes from documents, field notes, and interviews or excerpts from videotapes, audiotapes, or electronic communications are used to present the findings of the study. Content analysis is used to analyze the data. According to Moore \& Mc Cabe (2005), this is the type of research whereby data gathered is categorized in themes and sub-themes, so as to be able to be comparable. A main advantage of content analysis is that it helps in data collected being reduced and simplified; while at the same time producing results that may then measured using quantitative techniques.

Moreover, content analysis gives the ability to researchers to structure the qualitative data collected in a way that satisfies the accomplishment of research objectives.

\section{Discussion}

The data in this study is a movie premiered on February 7, 2002, about the relationship between love at school. This movie is identical with the local dialect, namely Jakarta dialect. There are many local features of Jakarta that are the hallmark of this movie. Most characters in the movie are teenagers. Teanager are close to the use of colloquial expression. That is why colloquial expression can be found in the movie. The following is colloquial data taken from the movie. There are several informal languages used in the movie.

\section{a. Slang}

\begin{tabular}{|l|c|c|c|}
\hline No. & Act & Colloquial Expression & Meaning \\
\hline 1. & 1 & Gue & I, me \\
\hline 2. & 1 & ngedance & Dance \\
\hline 3. & 5 & Please & Please \\
\hline 4. & 6 & Cepet-cepet & Quickly \\
\hline 5. & 7 & Sok & Arrogant \\
\hline 6. & 10 & Bete & Annoyed \\
\hline 7. & 12 & Nyari & Look for \\
\hline 8. & 16 & Konglomerat & Very wealthy \\
\hline 9. & 20 & Ngedate & Date \\
\hline 10. & 28 & Cuek & Ignorant \\
\hline 11. & 33 & Havefun & Have fun \\
\hline 12. & 36 & Hayo & Let's \\
\hline
\end{tabular}

The above table shows there are 12 occurance of slang expression found in the movie. Those data prove that the movie contains a lot of Jakarta dialect. These can be identified that the setting of this movie was in Jakarta. Many local dialect words of Jakarta are used in the movie.

\section{b. Jargon}

\begin{tabular}{|l|c|c|c|}
\hline No. & Act & Colloquial Expression & Meaning \\
\hline 1. & 5 & Editing & Editing \\
\hline 2. & 6 & Mading & Bulletin Board \\
\hline 3. & 18 & Manggung taktik & Tactical Gig \\
\hline 4. & 21 & Vonis & Verdict \\
\hline 5. & 27 & Naskah & Script \\
\hline
\end{tabular}


There are five occurances of Jargon expression in the movie. The five jargon above are common to see in the movie as the characters are teenagers. They tend to use such jargon.

\section{c. Provanity}

\begin{tabular}{|l|c|c|c|}
\hline No. & Act & Colloquial Expression & Meaning \\
\hline 1. & 4 & Gila & Crazy \\
\hline 2. & 4 & Resek & Nosy \\
\hline 3. & 7 & Belagu & Crotchety \\
\hline 4. & 7 & Timbal & Stubborn \\
\hline 5. & 24 & Bakalan Ganggu & Disturbing \\
\hline 6. & 27 & Keluarga Alien & Alien Family \\
\hline 7. & 29 & Monyet & Rough/redicule \\
\hline
\end{tabular}

These espressions show that the characters in the movie tend to express their emotion strongly. Even, there is a very rough word in the act 29 . In daily conversation, the word Monyet does not mean a kind of animal. This word is to state that the one or someone is insolent. This shows very rediculies or roughexpression. This proves that this movies present daily conversation which tends to be informal.

\section{d. Contraction}

\begin{tabular}{|l|c|c|c|}
\hline No. & Act & Colloquial Expression & Meaning \\
\hline 1. & 7 & $\mathrm{Tu}$ & That \\
\hline 2. & 18 & $\mathrm{Tu}$ & That \\
\hline 3. & 27 & $\mathrm{si}$ & The .... \\
\hline
\end{tabular}

There are three contraction expressions in the movie. Two expressions are the contractions of the demonstratice pronoun that. It means Itu in Bahasa Indonesia. Tu is the shortened form of itu in Bahasa Indonesia. Then, si refers to someone of something. It is equal to a definite article the.

\section{e. Idiom}

\begin{tabular}{|l|c|c|c|}
\hline No. & Act & Colloquial Expression & Meaning \\
\hline 1. & 13 & Anjing Gonggong & A barking dog \\
\hline
\end{tabular}

The following table shows the total occurances of each colloquial expression in the movie.

\begin{tabular}{|l|c|c|c|}
\hline No. & $\begin{array}{c}\text { Types of } \\
\text { Colloquial } \\
\text { Expression }\end{array}$ & $\begin{array}{c}\text { Number of } \\
\text { Occurances }\end{array}$ & Percentage \\
\hline 1. & Slang & 12 & $42.9 \%$ \\
\hline 2. & Jargon & 5 & $17.9 \%$ \\
\hline 3. & Provanity & 7 & $25 \%$ \\
\hline 4. & Contraction & 3 & $10.7 \%$ \\
\hline 5. & Idiom & 1 & $3.5 \%$ \\
\hline \multicolumn{2}{|c|}{ Total } & 28 & $100 \%$ \\
\hline
\end{tabular}

There are twenty eight occurances of colloquial expression found in the movie. Slang is the most dominant expression which occurs in the movie. It reaches $42.9 \%$ occurances. Next is provanity with $25 \%$ occurances. Jargon is presented with $17.9 \%$ in 
the movie. Contraction and idiom are with $10.7 \%$ and $3.5 \%$ each. This poves that there are lots of informal expression used in the movie. The most dominat expression, slang proves that the movie presents informal conversation among the characters. It is also shown by the teenager's story. Then, the second expression is provanity. It shows that the coversation is rather espressed strongly with emotion of the charactres because such provanity is strong emphasis on emotional expression.

From the above data, it can be seen that lots of particles of colloquial expression in Bahasa Indonesia can be found in the movie. This movie presents the local dialect of Jakarta. It proves that the setting of the movie is in Jakarta. The characters are tenagers in Jakarta. It portrays the colloquial language in bahasa Indonesia used in Jakarta. Through the analysis, it can be seen that there are lots of particles of Bahasa Indonesia . This enriches the expression in Bahasa Indonesia. This study also proves that Bahasa indonesia is rich in local dialect. Almost each region in Indonesia has it own local dialect of Bahasa Indonesia. In short, this movie can be as the medium to show up the local dialect of Jakarta in using Bahasa Indonesia.

\section{Conclusion}

From the result of the analysis, it can be concluded that there are five colloquial expressions found in the movie. They are slang, jargon, provanity, contraction and idiom. These expressions characterize the local dialect in Indonesia. The local dialect used in the movie is Jakarta dialect. It can be proved that the movie is set in Jakarta. The story presents the daily conversation the region. Through the analysis, it can be concluded that such colloquial expressions are indentically used by teenagers. It is also proved that most characters in the movie are teenagers. All in all, the movie presents a teenager story with daily conversation in informal context or situation.

\section{ACKNOWLEDGEMENTS}

The Writer would like to thank his supervisor, Muhammad Kiki Wardana, S.S., M.A and all the lecturers of the Faculty of Language and Communication at Harapan Medan University for the guidance, support and knowledge they have provided him. The writer also thanks the families of father, mother, brother and sister who always pray for him. Finaly, he expresses his gratitute to this journal, Journal of Language, Faculty of Literature, UISU for giving him chance to get his scientific article published in it.

\section{References}

Al Khulli, Muhammad Ali. (1976). English A Foreign Language: linguistic background and teaching method. Riyadh: Riyadh Universityn Publications.

Allan, Keith \& Burridge, Kate. (2006). Forbidden words: Taboo and the censoring of language. 1-303. 10.1017/9780511617881. https://www.researchgate.net/publication/288166020_Forbidden_words_Taboo_ and the censoring of language

Ary, Donal et al. (2010). Introduction to reseacrh in education (Eighth Edition). United States of Amerika: Wadsworth.

Bogdan, Robert C. and Biklen, Sari Knop. 1982. Qualitative Research for Education: An Introduction to Theory and Methods. Boston: Allyn and Bacon, Inc.

Brown, Steven and Attardo, Salvatore. (2000). Understanding language structure, interaction, and variation. Michigan: Michigan Teacher Training. 
Colloquial Language Used in Movie Script Ada Apa Dengan Cinta 1, Imam Arif Hidayat, Muhammad Kiki Wardana

Chaer, Abdul. 2003. Linguistik umum. Jakarta: Rineka Cipta.

Coupland, Nikolas (ed.), (2016). Sociolinguistics: theoretical debates. Cambridge: Cambridge University Press.

Coulmas, F. (ed.) (1997) The handbook of sociolinguistics. Oxford: Blackwell.

Creswell, J. W. (2012). Educational research: Planning, conducting, and Evaluating quantitative and qualitative research (4th ed.). New Jersey: Merrill.

Figueroa, E. (1994). Socio linguistic meta theory. Oxford: Pergamon.

Fishman, Joshua A. (1989). Language and ethnicity in minority sociolinguistic perspective. Clevedon: Multilingual Matters.

Fromkin, et. Al. (2011). An introduction to language, ninth edition. Canada: Wadsworth, Cengage Learning.

Hasanah, Dhia. (2020). The Use of Colloquial Words in Improving Students' Speaking Through Teacher's Daily Assessment. 10.2991/assehr.k.200406.007.

Hornby A.S.. (2000). Oxford advanced learners of current english. New Yor : Oxford University Press

Hudson, R. A. (1996). Sociolinguistics. Cambridge: Cambridge University Press.

Jalalpour, Elham \& Tabrizi, Hossein. (2017). A Study of English Translation of Colloquial Expressions in Two Translations of Jamalzadeh: Once Upon a Time and Isfahan Is Half the World. Journal of Language Teaching and Research. 8. 1011.

10.17507/jltr.0805.24. https://www.researchgate.net/publication/319431702_A_Study_of_English_Tra nslation_of_Colloquial_Expressions_in_Two_Translations_of_Jamalzadeh_Onc e_Upon_a_Time_and_Isfahan_Is_Half_the_World

Johnson, R. B. \& Christensen, L. B. (2008). Educational research: quantitative, qualitative, and mixed approaches (3 rd ed.). California: Sage.

Larson, M.L. (1984) Meaning-Based Translation: a guide to cross-language equivalence. Lanham: University Press of America.

Leech, G. N. (1969). A linguistic guide to english poetry. London: Longman

Leech, G. N., \& Short, M. H. (1981). Style in fiction. London: Longman.

Ljung, Magnus. (2011). Swearing: a crosscultural linguistic study. UK: Palgrave Macmillan.

Moon, R. (1998). Fixed expressions and idioms in english. A Corpus-Based Approach. United States: Oxford University Press

Moore, D. S., \& Mc Cabe, G. P. (2005). Introduction to the practice of statistics (5th ed.). New York:W.H. Freeman \& Company

Nurgiyantoro, Burhan. (1994). Teori pengkajian fiksi. Yogyakarta: Gadjah Mada University Press.

Quirck, R. (2001). Longman dictionary of contemporary english. England: Longman Group Limited.

Spolsky, B. (1998). Sociolinguistics: oxford introduction to language study. Oxford: Oxford University Press.

Srijono, D. (2001). An introductory course of linguistics. Surakarta: Muhammadiyah University Press.

Swan, M. (1995). Practical english usage (2nd edition). Oxford: OUP oxford.

Torchia, C. (2007). Indonesian Idioms and Expressions: colloquial Indonesian at work. Tokyo: Tuttle Publishing

Turner, G. W. (1977). Stylistics. New York: Penguin Books. 
Williams, G. (1992). Sociolinguistics: parsonian structural functionalism. Britania: Routledge

Wardhaugh, R. (1998). An introduction to socio linguistics (6th edn). Oxford: Blackwell.

Wright. J. (2002). Idioms Organizer: organized by metaphor, topic and key word. Croatia: Thomson-Heinle.

Yule, George. (2010). The study of language (4th Ed.). Cambridge: Cambridge University Press . (2005). Slang Particles in Indonesian Language: Partikel dalam Percakapan Bahasa Indonesia. Retrieved from http://inggrisindo.blogspot.com/2008/02/slang-particles-in-indonesianlanguage.html 